\title{
COVID-19: global pandemic with divergent waves: an exigent public health concern worldwide with special context to Indian scenario
}

\author{
Shehna Sharaf ${ }^{1}$, Faisal Moossa Athikkavil ${ }^{2}$, Shiny Deena Varghese ${ }^{1}$, Sreelekshmi Sreekumar', \\ Reshmi Ramakrishnan ${ }^{1}$, Jeslin Varghese ${ }^{1}$, Lakshmi Sree Dharan Pillai ${ }^{1 *}$, \\ Saikant Regidi ${ }^{1}$, Abi Santosh Aprem ${ }^{1}$
}

\begin{abstract}
${ }^{1}$ Corporate Research and Development Centre, HLL Lifecare Ltd., Government of India Enterprise, Akkulam, Thiruvananthapuram, Kerala, India

${ }^{2}$ Department of Biotechnology, University of Calicut, Kerala, India
\end{abstract}

Received: 15 January 2022

Accepted: 15 February 2022

\section{*Correspondence:}

Dr. Lakshmi Sree Dharan Pillai,

E-mail: lakshmideependran08@gmail.com

Copyright: () the author(s), publisher and licensee Medip Academy. This is an open-access article distributed under the terms of the Creative Commons Attribution Non-Commercial License, which permits unrestricted non-commercial use, distribution, and reproduction in any medium, provided the original work is properly cited.

\begin{abstract}
The review discusses, how the COVID-19 virus evolved to the present form, genome organization and genetic variation of SARS- CoV-2 prevalent globally with special emphasis on Indian strains, a comparison of the first vs. second wave in terms of infectivity and transmission patterns. The population impacted, importance of surveillance, study of genetic variants of COVID-19 virus, development of diagnostics developed in First and second waves of infection and preventive measures like physical means, vaccine administration and treatment strategies using different classes of anti-viral, anti-inflammatory, antibiotic and corticosteroid drugs. The study used the detailed and qualitative online research. The literature studies were conducted to explore the havoc of the COVID-19 Pandemic from the very beginning era to current and future repercussions in worldwide with special context to India. The idea of our work is to be on a high alert and vigilant in the constant studying of the varying characteristics of the pandemic and to produce resources and be able to modify treatment methodologies quickly, if needed, and disseminate our work to the scientific world and community as soon as possible for coordinating a global action to cut off the inevitable future waves of this pandemic. Securing vaccine is the most concern, along with the strategies that could be forward to strengthen the health care system. This paper gives insight by warning the third wave, unless taken utmost care by each individual, national as well international organization could be catastrophic to the entire World.
\end{abstract}

Keywords: Transmission, Mutant viral strains, SARS-CoV-2, Anti-viral, Anti-inflammatory

\section{INTRODUCTION}

Pandemics are never a new term as it was there earlier and will exist in the future too if not looked upon. From the onset of the $21^{\text {st }}$ century, we have witnessed several emanations and outbreaks of multiple zoonotic pandemics and infectious diseases which are caused by bacteria, viruses, and several other organisms that are transferred from animals to human beings. 1,2

Since 2000 we have been troubled with three pandemics, namely severe acute respiratory syndrome (SARS) in
2003, H1N1 swine flu in 2009 and, now novel coronavirus-COVID-19. ${ }^{3,4}$ SARS-CoV-2 also known as covid19 virus is a zoonotic pathogenic viral disease of bat origin as it could be the possible primary reservoir, however intermediate root of origin and further transfer to humans was in doubt or unknown. 5,6

\section{SARS-CoV-2 pandemic emanation to the present}

The onset of SARS-CoV-2 (novel coronavirus) started on December, 2019 as zoonotic transmission from in Wuhan, China, which is also considered as the epicenter for the 
virus outbreak. ${ }^{7}$ This new pandemic was named as severe acute respiratory syndrome coronavirus-2 (SARS-CoV-2, Covid19) as it shared around $\sim 89 \%$ homology with a category of SARS-like Coronaviruses of bats in China (genus Beta coronavirus). ${ }^{8,9}$ The First sequence to be shared of Covid19 on the National Center for Biotechnology Information (NCBI-GenBank) was with the accession id NC_045512.2 (NCBI Curated and Updated). The virus induced a series of symptoms in which the prime immediate mortality factors were septic shock, multiple organ dysfunction and, ARDS (acute respiratory distress syndrome). ${ }^{10}$ Subsequently, the highly contagious transmission between humans was also a key factor in declaring this viral disease as a global pandemic (WHO). Epidemiological reports suggest the most affected ones are elderly and the mortality rate is higher as compared to children. ${ }^{11,12}$ Approximately around 200 countries and territories are under this viral attack and as of May 14th, 2021, after the first and second wave, around 160 million cases along with 3.33 million deaths have been reported worldwide and are subjected to increase further rapidly as stated by the centre for systems science and engineering (CSSE) at John Hopkins University. ${ }^{13,14}$

\section{First wave vs. second wave: how different?}

In India the initial cases were reported from Kerala state, among the passengers who returned back from Wuhan, China on the $30^{\text {th }}$ January \& $3^{\text {rd }}$ February $2020 .{ }^{15}$ Further, two more cases were reported between the Indian returnees from Italy and Dubai and the cases began to increase slowly. On $18^{\text {th }}$ June 2020, India reported 11,000 cases and the following two months, it added on about an average of new 35,000 plus cases every day. The first wave of the covid19 virus spike was seen in 2020 September which decreased gradually. Nearly after six months the coronavirus cases in India started to climb in early March 2021, marking the onset of the pandemic covid19's second wave within the country. During the second wave, India confirmed about 22,000 on March $10^{\text {th }} 2021$ with an average of 18,000 cases per day and in the next 30 days, the daily average rose sharply over $3,90,000$ cases creating havoc in the country. Experts state that the second wave's faster spreading nature accounts for such a steep increase of cases across the country. Presently India overtook all the other countries, and emerged as one of the worst hit nation of the second wave of coronavirus. ${ }^{16}$ Several countries have observed a two-wave pattern in the COVID-19 pandemic cases. ${ }^{17}$ The data reports suggests that the characteristics nature and the way virus attacks do vary between the two waves and there is also a slight variation in the age group and severity of the illness. ${ }^{18,19}$ The most common indications were mentioned in (Figure 1, Table 1) ${ }^{20,21}$ Furthermore, early reports states that the asymptomatic cases are higher in the second wave the genetic double mutant variant has more transmissibility rate. ${ }^{22}$
The prime victims of this pandemic still continue to be the older population as they are the most vulnerable ones. However, a slight increase has been seen in younger age people getting infected with the coronavirus. The percentage of the affected cases are depicted in the (Table

Table 1: Covid-19: first wave vs. second wave.

\begin{tabular}{|c|c|c|}
\hline Profile & First wave & Second wave \\
\hline Mortality & $\begin{array}{l}\text { Older people }>50 \\
\text { years of age }\end{array}$ & $\begin{array}{l}\text { Under } 45 \\
\text { years of age }\end{array}$ \\
\hline $\begin{array}{l}\text { Number of } \\
\text { positive cases }\end{array}$ & $\begin{array}{l}\text { Older people }>50 \\
\text { years of age }\end{array}$ & $\begin{array}{l}\text { Under } 45 \\
\text { years+ } \\
\text { children }\end{array}$ \\
\hline $\begin{array}{l}\text { Average age of } \\
\text { Patients }\end{array}$ & Mainly 50+ & Mainly 49+ \\
\hline $\begin{array}{l}\text { Infection } \\
\text { among } 30-45 \\
\text { years of age }\end{array}$ & $21 \%$ & $21 \%$ \\
\hline $\begin{array}{l}\text { Infection } \\
\text { under } 30 \\
\text { years of age }\end{array}$ & $31 \%$ & $32 \%$ \\
\hline $\begin{array}{l}\text { Hospitalization } \\
\text { Requirement } \\
\text { age } 0-19\end{array}$ & $4.2 \%$ & $5.8 \%$ \\
\hline $\begin{array}{l}\text { Hospitalization } \\
\text { Requirement } \\
\text { age } 20 \text {-39 }\end{array}$ & $23.7 \%$ & $25.5 \%$ \\
\hline
\end{tabular}

\section{Genome organization - novel coronavirus}

SARS-CoV-2, a single stranded positive sense RNA virus of 26 to $32 \mathrm{~kb}$ with 6 to 14 open reading frames, use its spike protein to bind with ACE 2 which is primed by the host serine transmembrane protease TMPRSS2 cleave the viral proteins that helps to engage and bring the virus into the cell through receptor mediated endocytosis by cathepsin $\mathrm{L}$ which cause rapid infection which can lead to exacerbated immune responses based on the level of immune mediators and hence the complication varies in individuals and hence the transmission of the virus which leads to the mutant variants. ${ }^{23-27}$

\section{Global mutant variants}

Like all viruses, SARS-CoV-2 rack up mutations at a slower rate that leads to the changes in the genetic code over time as it replicates with an inherent repair mechanism due to higher genomic nucleotide substitution and recombination rates. As per the SARS-CoV-2 Interagency Group (SIG), Centers for Disease Control and Prevention, three set of variants being monitored based on the global impact as variants of interest, concern and high consequence. ${ }^{28,29}$

\section{Variants in play in India}

As per the recent studies new specific variant B.1.617, found in Vidarbha region of Maharashtra, detected with double mutations, E484Q and L452R similar to the 
lineage B.1.1.7 from United Kingdom and B.1.351 from South Africa in key areas make the spike protein more infectious which could be able to escape the immune system. ${ }^{30}$

Table 2: Genetic variants correspond with specified lineage, spike protein substitutions with the name of the strain and country first detected.

\begin{tabular}{|c|c|c|c|}
\hline $\begin{array}{l}\text { Name } \\
\text { (lineage) }\end{array}$ & Spike Protein Substitutions & $\begin{array}{l}\text { Name } \\
\text { (next strain) }\end{array}$ & First detected \\
\hline B.1.526 & $\begin{array}{l}\text { (L5F*), T95I, D253G, (S477N*), (E484K*), D614G, } \\
\left(\mathrm{A} 701 \mathrm{~V}^{*}\right)\end{array}$ & $\begin{array}{l}20 \mathrm{C} / \\
\mathrm{S}: 484 \mathrm{~K}\end{array}$ & $\begin{array}{l}\text { United States (New York) - } \\
\text { November } 2020\end{array}$ \\
\hline B.1.526.1 & $\begin{array}{l}\text { D80G, } \Delta 144, \text { F157S, L452R, D614G, } \\
\left(\mathrm{T} 791 \mathrm{I}^{*}\right),\left(\mathrm{T} 859 \mathrm{~N}^{*}\right), \mathrm{D} 950 \mathrm{H}\end{array}$ & $20 \mathrm{C}$ & $\begin{array}{l}\text { United States(New York) -October } \\
2020\end{array}$ \\
\hline B.1.525 & $\begin{array}{l}\text { A67V }, \Delta 69 / 70, \Delta 144, E 484 K, D 614 G, Q 677 H, \\
\text { F888L }\end{array}$ & $\begin{array}{l}20 \mathrm{~A} / \\
\mathrm{S}: 484 \mathrm{~K}\end{array}$ & $\begin{array}{l}\text { United Kingdom/Nigeria- } \\
\text { December } 2020\end{array}$ \\
\hline P.2 & $\mathrm{E} 484 \mathrm{~K},\left(\mathrm{~F} 565 \mathrm{~L}^{*}\right), \mathrm{D} 614 \mathrm{G}, \mathrm{V} 1176 \mathrm{~F}$ & $20 \mathrm{~J}$ & Brazil - April2020 \\
\hline B.1.617 & L452R,E484Q, D614G & $20 \mathrm{~A}$ & India -February 2021 \\
\hline B.1.617.1 & $\begin{array}{l}\text { (T95I), G142D, E154K, L452R, E484Q, } \\
\text { D614G,P681R,Q1071H }\end{array}$ & $\begin{array}{l}20 \mathrm{~A} / \\
\mathrm{S}: 154 \mathrm{~K}\end{array}$ & India -December 2020 \\
\hline B.1.617.2 & $\begin{array}{l}\text { T19R, (G142D), } \Delta 156, \Delta 157, \\
\text { R158G, L452R, T478K, D614G, P681R, D950N }\end{array}$ & $\begin{array}{l}20 \mathrm{~A} / \\
\mathrm{S}: 478 \mathrm{~K}\end{array}$ & India -December 2020 \\
\hline B.1.617.3 & $\begin{array}{l}\text { T19R, G142D, L452R, E484Q, D614G, P681R, } \\
\text { D950N }\end{array}$ & $20 \mathrm{~A}$ & India -October 2020 \\
\hline B.1.1.7 & $\begin{array}{l}\Delta 69 / 70, \Delta 144,\left(E 484 K^{*}\right),(\text { S494P*), N501Y, } \\
\text { A570D, D614G, P681H, T716I, S982A, } \\
\text { D1118H(K1191N*) }\end{array}$ & $\begin{array}{l}\text { 20I/ } \\
501 \mathrm{Y} . \mathrm{V} 1\end{array}$ & United Kingdom-December 2020 \\
\hline P.1 & $\begin{array}{l}\text { L18F, T20N, P26S, D138Y, R190S, K417T, E484K, } \\
\text { N501Y, D614G, H655Y, T1027I }\end{array}$ & 20J/501Y.V3 & Japan/ Brazil- January 2021 \\
\hline B.1.351 & $\begin{array}{l}\text { D80A, D215G, } 4241 / 242 / 243, \mathrm{~K} 417 \mathrm{~N}, \mathrm{E} 484 \mathrm{~K} \text {, } \\
\text { N501Y, D614G, A701V }\end{array}$ & $20 \mathrm{H} / 501 . \mathrm{V} 2$ & $\begin{array}{l}\text { South Africa-October } 2020 \text { and } \\
\text { later in United Kingdom January } \\
2021\end{array}$ \\
\hline B.1.427 & L452R, D614G & $20 \mathrm{C} / \mathrm{S}: 452 \mathrm{R}$ & $\begin{array}{l}\text { United States-(California)- } \\
\text { February } 2021\end{array}$ \\
\hline B.1.429 & S13I, W152C, L452R, D614G & 20C/S:452R & $\begin{array}{l}\text { United States-(California)- } \\
\text { February } 2021\end{array}$ \\
\hline
\end{tabular}

Other variant with fast-transmission emerged in the United Kingdom, called B 1.1.7 that has been found to be present in large numbers in northern India, could also be a possible impact for the quick rise in cases (Table 3-5).

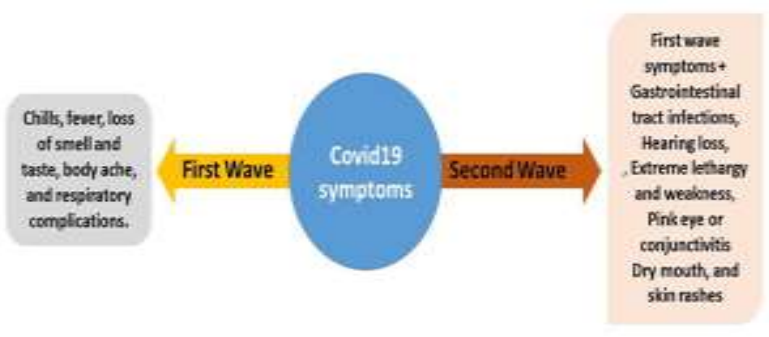

Figure 1: COVID-19 Symptoms, first wave vs. second wave.

\section{Importance of surveillance and study of genetic variants of COVID-19 virus}

The genomic epidemiology is also a developing field in the mitigation and control of the SARS-CoV-2 outbreak. Thousands of changes in the genome have already been reported with a potential to increase transmission among public. India has submitted more than 60,000 SARSCoV-2 viral genomes via many labs in the country. ${ }^{34}$ The presence of novel coronavirus genetic variants among patients may also make an impact on the performance of diagnostic tests. Some false results will occur even when very accurate SARS-CoV-2 tests are being used. This novel coronavirus mutations and its impact on testing has been strictly tracked by the FDA throughout. The molecular surveillance based on real-time viral genomic data is really important for a timely management of the pandemic.

\section{Development of diagnostics}

As per WHO guidelines, validated RT-PCR assay should target at least two regions of SARS- CoV-2 viral genome. Most of the kit manufactures used viral gene targets nucleocapsid $(\mathrm{N})$, envelope (E), spike (S), and RNA dependent RNA polymerase (RdRP) genes in the RTPCR test kits which are highly sensitive and specific. Hence, globally Nucleic acid amplification tests (NAAT) based RT-PCR technique is currently a gold standard test used for routine confirmation of cases of COVID-19. 


\section{Preventive strategies}

Self-awareness of preventive measures including adoption of a healthy lifestyle and diet, physical exercise, optimal metabolic control, vitamin D intake is very important to prevent spread of disease. The management of COVID-19 include improving hygiene level, identification infected persons and proper isolation, lockdown and wearing Masks. ${ }^{35}$

Table 3: Most prevalent SARS-CoV-2 mutations in India: summary of the top 61 non-synonymous Indian variants of SARS-CoV-2 (arranged by prevalence) listing the genomic mutation and the corresponding amino acid change in the associated viral protein.

\begin{tabular}{|c|c|c|c|c|}
\hline Variant & Protein_position & Protein_mutation & Prevalence & Percentage \\
\hline A23403G & S:614 & D614G & 4430 & 82.29 \\
\hline C14408T & ORF1b:314 & P314L & 4375 & 81.12 \\
\hline G28881A & $\mathrm{N}: 203$ & R203K & 2096 & 38.87 \\
\hline G28883C & $\mathrm{N}: 204$ & G204R & 2086 & 38.68 \\
\hline G28882A & $\mathrm{N}: 203$ & R203K & 2086 & 38.68 \\
\hline G25563T & ORF3a:57 & Q57H & 1256 & 23.29 \\
\hline C5700A & ORF1a:1812 & A1812D & 1209 & 22.42 \\
\hline C28854T & $\mathrm{N}: 194$ & S194L & 1096 & 20.32 \\
\hline G11083T & ORF1a:3606 & L3606F & 761 & 14.11 \\
\hline C13730T & ORF1b:88 & A88V & 655 & 12.15 \\
\hline C28311T & $\mathrm{N}: 13$ & P13L & 650 & 12.05 \\
\hline C6312A & ORF1a:2016 & T2016K & 593 & 11 \\
\hline C8917T & ORF1a:2884 & $\mathrm{F} 2884 \mathrm{~F}$ & 447 & 8.29 \\
\hline C6573T & ORF1a:2103 & S2103F & 301 & 5.58 \\
\hline G9389A & ORF1a:3042 & D3042N & 300 & 5.56 \\
\hline C25528T & ORF3a:46 & L46F & 295 & 5.47 \\
\hline T1947C & ORF1a:561 & V561A & 234 & 4.34 \\
\hline C9693T & ORF1a:3143 & $\mathrm{A} 3143 \mathrm{~V}$ & 215 & 3.99 \\
\hline C3267T & ORF1a:1001 & T1001I & 192 & 3.56 \\
\hline G26173T & ORF3a:261 & E261* & 190 & 3.52 \\
\hline C21034T & ORF1b:2523 & L2523F & 187 & 3.47 \\
\hline G28183T & ORF8:97 & S97I & 187 & 3.47 \\
\hline T28277C & $\mathrm{N}: 2$ & $\mathrm{~S} 2 \mathrm{P}$ & 163 & 3.02 \\
\hline C1218T & ORF1a:318 & S318L & 121 & 2.24 \\
\hline
\end{tabular}

\section{Vaccines}

Vaccination helps to prevent infection or to reduce disease severity, shedding of virus meanwhile controlling transmission and disease outbreak. ${ }^{36}$ Vaccines such as Moderna's mRNA-1273, Astra Zeneca's AZD1222, Johnson and Johnson's Ad26.COV2.S and Pfizer/BioNTech's Comirnaty are authorized vaccines and recommended for prevention of COVID-19 virus infection. ${ }^{37}$

Vaccines reduce mortality and taking vaccine is more cost effective than treatment. Inovio pharmaceuticals company has developed a DNA vaccine named INO-4800 to prevent COVID-19 infection which induces $\mathrm{T}$ cell activation by delivering DNA plasmids that express $\mathrm{S}$ protein of coronavirus. ${ }^{38}$ One of the mRNA vaccine Moderna (vaccine mRNA-1273) is a lipid nanoparticleencapsulated, nucleoside-modified vaccine that encode Sglycoprotein stabilized in its prefusion conformation.
Oxford AstraZeneca COVID19 vaccine, sold with other names such as Covishield and Vaxzevria, is developed by Oxford university and AstraZeneca. It is an adenovirus vector vaccine achieving humoral responses against spike glycoprotein receptor binding domain of COVID-19 virus by day 28 as well as T-cell responses.

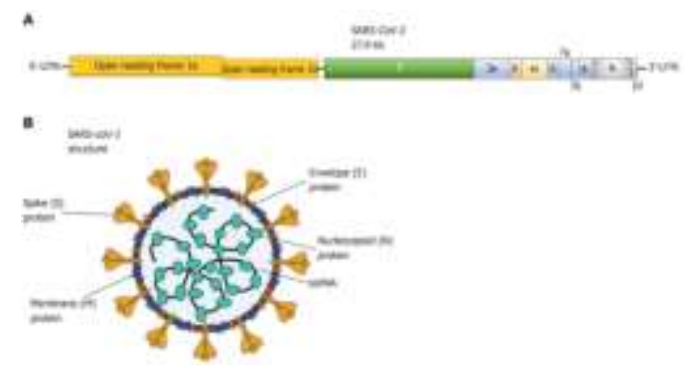

Figure 2: A) Representation of the genomic organization of SARS-CoV-2; B) Diagram of the structural features of SARS-CoV-2. 
The vaccine consist of an mRNA drug material that is incorporated into lipid nanoparticles (LNPs) which contains three commercially available lipids such as cholesterol, DSPC and polyethylene glycol PEG 2000 DMG (dimyristoyl glycerol) and SM-102.

Wuhan institute of biological products and institute of medical biology, Chinese academy of medical sciences are prime developers of inactivated virus vaccines. Protein subunit vaccines are full length recombinant coronavirus glycoprotein nanoparticle vaccine adjuvant with Matrix M TM adjuvant. As a simplified vaccine delivery method, dissolvable microneedle patches are to be considered as a possible ticket for future pandemic coronavirus infections.

\section{Treatment options of $1^{\text {st }}$ And $2^{\text {nd }}$ wave}

The patients with early disease benefit more when treated with antiviral agents, hence timing of the treatment is very crucial.

Table 4: Most prevalent SARS-CoV-2 mutations in India: summary of the top 61 non-synonymous Indian variants of SARS-CoV-2 (arranged by prevalence) listing the genomic mutation and the corresponding amino acid change in the associated viral protein.

\begin{tabular}{|c|c|c|c|c|}
\hline Variant & Protein_position & Protein_mutation & Prevalence & Percentage \\
\hline G21724T & $\mathrm{S}: 54$ & L54F & 115 & 2.13 \\
\hline G28878A & $\mathrm{N}: 202$ & S202N & 104 & 1.93 \\
\hline A4372G & ORF1a:1369 & G1369G & 103 & 1.91 \\
\hline T28144C & ORF8:84 & L84S & 103 & 1.91 \\
\hline G29474T & $\mathrm{N}: 401$ & D401Y & 93 & 1.72 \\
\hline A21551T & ORF1b:2695 & $\mathrm{N} 2695 \mathrm{~L}$ & 87 & 1.61 \\
\hline A21550C & ORF1b:2695 & $\mathrm{N} 2695 \mathrm{~L}$ & 87 & 1.61 \\
\hline C10815T & ORF1a:3517 & $\mathrm{S} 3517 \mathrm{~F}$ & 84 & 1.56 \\
\hline C6310A & ORF1a:2015 & S2015R & 80 & 1.48 \\
\hline A2292C & ORF1a:676 & Q676P & 74 & 1.37 \\
\hline C18568T & ORF1b:1701 & L1701F & 73 & 1.35 \\
\hline C16726T & ORF1b:1087 & $\mathrm{H} 1087 \mathrm{Y}$ & 71 & 1.32 \\
\hline C21575T & S:5 & L5F & 70 & 1.3 \\
\hline G23593T & S:677 & Q677H & 70 & 1.3 \\
\hline G11417T & ORF1a:3718 & V3718F & 67 & 1.24 \\
\hline G1820A & ORF1a:519 & G519S & 63 & 1.17 \\
\hline C20384T & ORF1b:2306 & A2306V & 61 & 1.13 \\
\hline G3871T & ORF1a:1202 & $\mathrm{K} 1202 \mathrm{~N}$ & 60 & 1.11 \\
\hline C19862T & ORF1b:2132 & A2132V & 58 & 1.08 \\
\hline G8371T & ORF1a:2702 & $\mathrm{Q} 2702 \mathrm{H}$ & 58 & 1.08 \\
\hline C26447T & E:68 & S68F & 58 & 1.08 \\
\hline T25556G & ORF3a:55 & V55G & 58 & 1.08 \\
\hline G21974T & $\mathrm{S}: 138$ & D138Y & 56 & 1.04 \\
\hline C23604A & S:681 & P681H & 53 & 0.98 \\
\hline
\end{tabular}

The patients with severe and late disease may benefit from anti-inflammatory drugs also. ${ }^{39,40}$ Several traditional medicines could also be used for treatment of COVID-19 and studies were conducted in elucidating the medicinal value of herbal medicines as well the molecular targets for the new developing drugs as in (Figure 3, Table 6).

\section{Drugs and vaccines in trial}

Anti-Covid oral drugs-2-DG developed by Govt. of India found the efficacy of the 2-DG drug against SARS - CoV2 based on the preliminary experiments inside the lab and DCGI authorized to direct the phase II clinical trials. The trials exhibited significant signs of recovery in patients. Following the effective phase-II trials in the middle of 2020, the 2-DG undergo phase-IIa/phase-IIb trials, at hospitals conducted on 110 patients and received approval for Phase-III trials by DCGI in November 2020. Molnupiravir is an experimental oral antiviral originally developed to treat influenza can be used against SARSCOV-2 by inhibition of RNA-dependent-RNA polymerase. The Phase III clinical trials was started on May 2021 by Yashoda hospital in tie up with Natco pharma who received DCGI approval for oral administration for patients with mild and moderate symptoms. 
Nasal spray vaccine shows promise in animal trials and clinical trial by Bharat biotech

Based on the reports from Lancaster university in England and Texas Biomedical Research Institute in San Antonio, a nasal spray vaccine showed strong effect against SARS-CoV2 on animals tested with two doses with reduced inflammation and lung damage by the production of antibodies and $\mathrm{T}$ cell responses. The Bharat biotech is aiming the first intranasal vaccine in India and had signed an agreement in association with virologics, at the Washington university school of medicine in St. Louis, US.

Table 5: Most prevalent SARS-CoV-2 mutations in India: summary of the top 61 non-synonymous Indian variants of SARS-CoV-2 (arranged by prevalence) listing the genomic mutation and the corresponding amino acid change in the associated viral protein.

\begin{tabular}{|lllll|}
\hline Variant & Protein_position & Protein_mutation & Prevalence & Percentage \\
\hline G28899T & N:209 & R209I & 53 & 0.98 \\
\hline G28209C & ORF8:106 & E106Q & 52 & 0.96 \\
\hline C26060T & ORF3a:223 & T223I & 52 & 0.96 \\
\hline T8022G & ORF1a:2586 & V2586G & 52 & 0.96 \\
\hline G28221T & ORF8:110 & E110* & 47 & 0.87 \\
\hline C11195T & ORF1a:3644 & L3644F & 47 & 0.87 \\
\hline C19154T & ORF1b:1896 & T1896I & 46 & 0.85 \\
\hline C6027T & ORF1a:1921 & P1921L & 44 & 0.82 \\
\hline T22882G & S: 440 & N440K & 43 & 0.8 \\
\hline C22227T & S: 222 & A222V & 5 & 0.09 \\
\hline G23012A & S: 484 & N501Y & 3 & 0.06 \\
\hline A23063T & S:501 & S477N & 1 & 0.04 \\
\hline G22992A & S: 477 & & 0.02 \\
\hline
\end{tabular}

Table 6: Drugs used for the treatment of COVID-19.

\begin{tabular}{|c|c|c|c|c|}
\hline Drug & Company & Initial target & Mode of action & $\begin{array}{l}\text { Mode of } \\
\text { administration }\end{array}$ \\
\hline \multicolumn{5}{|l|}{ Antiviral drugs } \\
\hline Remdesivir & Gilead & Ebola & Nucleotide analogue & intravenous \\
\hline $\begin{array}{l}\text { Chloroquine/hydroxyl- } \\
\text { chloroquine (aralen/plaquenil) }\end{array}$ & Sanofi & Malaria & $\begin{array}{l}\text { Heme polymerase } \\
\text { inhibitor }\end{array}$ & Oral \\
\hline Favipiravir (avigan) & Fujifilm & Influenza & $\begin{array}{l}\text { RNA polymerase } \\
\text { inhibitor }\end{array}$ & Oral \\
\hline Umifenovir (arbidol) & Pharmstandard & Influenza & $\begin{array}{l}\text { Inhibits membrane } \\
\text { fusion (entry) }\end{array}$ & Oral \\
\hline Camostat & Ono Pharmaceutical & Experimental & Protease inhibitor & Oral \\
\hline Ribavirin & Bausch Health & Hepatitis C & $\begin{array}{l}\text { Lower respiratory tract } \\
\text { infection due to RSV }\end{array}$ & Inhalation \\
\hline Lopinavir-ritonavir & Abbott & HIV & Inhibits 3CLpro & Oral \\
\hline \multicolumn{5}{|l|}{ Anti-inflammatory drugs } \\
\hline Interferon alfa- $2 b$ & & Hepatitis C & Immune modulator & Sub-cutaneous \\
\hline Tocilizumab (Actemra) & Roche & $\begin{array}{l}\text { Rheumatoid } \\
\text { arthritis }\end{array}$ & IL-6R Ab & intravenous \\
\hline Sarilumab (Kevzara) & Sanofi & $\begin{array}{l}\text { Rheumatoid } \\
\text { arthritis }\end{array}$ & IL-6R Ab & intravenous \\
\hline Baricitinib (Olumiant) & Eli Lilly & $\begin{array}{l}\text { Rheumatoid } \\
\text { arthritis }\end{array}$ & Inhibition of JAK & Oral \\
\hline
\end{tabular}

\section{Three waves of the COVID-19 pandemic}

We have already experienced high death toll and severe after effect of the COVID-19 even after clinically cured. ${ }^{41}$
The first wave has affected the most vulnerable sections of the population: the old, sick and the immunecompromised. The second wave started when the epidemic has spread into the general population, who do not have protective antibodies against the pathogen. The second wave affected those who suffer in the medium- 
terms due to measures taken to limit the spread of COVID-19, includes those with delayed presenting to health care due to fear, progressive diseases and it includes those who delay presenting to healthcare facilities for fear of COVID-19 infection and those missed the regular screening. Whereas, the third wave is expected to be on the next generation and it is clear that the third wave of this Covid19 virus is inevitable as when this wave will come and for how long could not be predicted. The second and the possible third waves of the infection is usually due to the strains that under gone mutation which have the capability to escape immunity offered. ${ }^{42,43}$

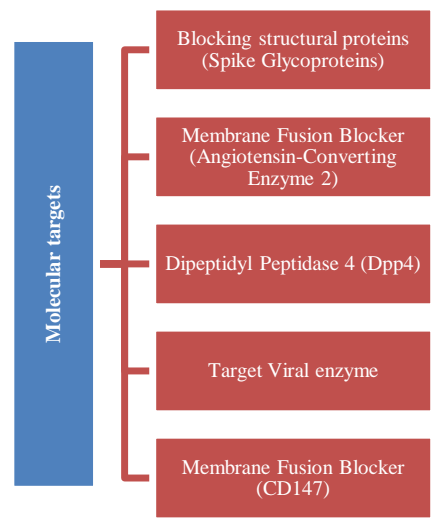

Figure 3: Molecular targets for new developing drugs against SARS-CoV-2.

\section{Possibilities of the third wave and repercussions}

Being prepared for the third COVID-19 wave hitting us is crucial. While securing vaccine is the most concern, along with the strategies that could be forward to strengthen the health care system. Experts opined that the third wave of COVID-19 will hit children in a big way and it is time for both the central and state governments to chalk out strategies. The third wave, when it hits developing countries like Africa, Asia and South America, could be the deadliest yet. Govt. of India explained that a third wave depends on how effectively all the guidelines are followed and implemented. The strategies to control the possibility of third wave of COVID-19 pandemic include screening, containment or suppression and mitigation by improving overall health; by early detection, and by improving quality of life, treatment as well recovery. The foremost primary prevention strategy is vaccination, to be taken against any infectious diseases which have been one of the greatest successes in medicine.

\section{CONCLUSION}

The point of our work is to be on a high alert and vigilant in the constant studying of the varying characteristics of the pandemic and be able to modify treatment methodologies quickly, if needed, and disseminate our work to the scientific world and community as soon as possible for coordinating a global action to cut off the inevitable future waves of this pandemic.

Funding: No funding sources

Conflict of interest: None declared

Ethical approval: Not required

\section{REFERENCES}

1. Lowenthal D, Jenkins S. Prizing the past for the present and the future. Br Acad Rev. 2011;18:34-40.

2. Mack A, Choffnes ER, Hamburg MA, Relman DA, editors. Microbial evolution and co-adaptation: a tribute to the life and scientific legacies of Joshua Lederberg: workshop summary. Nat Acad Press. 2009.

3. Brucker MC. Novel viruses, zoonotic infections, and travel health. Nurs Women's Health. 2020;24(2):65.

4. Zhong NS, Zheng BJ, Li YM, Poon LL, Xie ZH, Chan $\mathrm{KH}$, et al. Epidemiology and cause of severe acute respiratory syndrome (SARS) in Guangdong, People's Republic of China, in February, 2003. Lancet. 2003;362(9393):1353-8.

5. Jamieson DJ, Honein MA, Rasmussen SA, Williams JL, Swerdlow DL, Biggerstaff MS, et al. H1N1 2009 influenza virus infection during pregnancy in the USA. Lancet. 2009;374(9688):451-8.

6. Scalera NM, Mossad SB. The first pandemic of the 21st century: review of the 2009 pandemic variant influenza A (H1N1) virus. Postgrad Med J. 2009;121 (5):43-7.

7. Shereen MA, Khan S, Kazmi A, Bashir N, Siddique R. COVID-19 infection: Origin, transmission, and characteristics of human coronaviruses. J Adv Res. 2020;24:91.

8. Yuki K, Fujiogi M, Koutsogiannaki S. COVID-19 pathophysiology: A review. J Clin Immunol. 2020; 215:108427.

9. Wu F, Zhao S, Yu B, Chen YM, Wang W, Song ZG, et al. A new coronavirus associated with human respiratory disease in China. Nature. 2020;579 (7798):265-9.

10. Hu D, Zhu C, Ai L, He T, Wang Y, Ye F, et al. Genomic characterization and infectivity of a novel SARS-like coronavirus in Chinese bats. Emerg microbes \& infect. 2018;7(1):1-0.

11. Elezkurtaj S, Greuel S, Ihlow J, Michaelis EG, Bischoff P, Kunze CA, et al. Causes of death and comorbidities in hospitalized patients with COVID19. Sci Rep. 2021;11(1):1-9.

12. Lu X, Zhang L, Du H, Zhang J, Li YY, Qu J, et al. SARS-CoV-2 infection in children. N Engl J Med. 2020;382(17):1663-5.

13. Qiu H, Wu J, Hong L, Luo Y, Song Q, Chen D. Clinical and epidemiological features of 36 children with coronavirus disease 2019 (COVID-19) in Zhejiang, China: an observational cohort study. Lancet Infect Dis. 2020;20(6):689-96.

14. Zhang J, Litvinova M, Wang W, Wang Y, Deng X, Chen X, Li M, Zheng W, Yi L, Chen X, Wu Q. 
Evolving epidemiology and transmission dynamics of coronavirus disease 2019 outside Hubei province, China: a descriptive and modelling study. Lancet Infect Dis. 2020;20(7):793-802.

15. Zheng M, Gao Y, Wang G, Song G, Liu S, Sun D, $\mathrm{Xu} \mathrm{Y}$, Tian Z. Functional exhaustion of antiviral lymphocytes in COVID-19 patients. Cell Mol Immunol. 2020;17(5):533-5.

16. Fan G, Yang Z, Lin Q, Zhao S, Yang L, He D. Decreased case fatality rate of COVID-19 in the second wave: a study in 53 countries or regions. Transbound Emerg Dis. 2021;68(2):213-5.

17. Saito S, Asai Y, Matsunaga N, Hayakawa K, Terada M, Ohtsu H, Tsuzuki S, Ohmagari N. First and second COVID-19 waves in Japan: a comparison of disease severity and characteristics. J Infect. 2021; 82(4):84-123.

18. Long SW, Olsen RJ, Christensen PA, Bernard DW, Davis JJ, Shukla M, Nguyen M, Saavedra MO, Yerramilli P, Pruitt L, Subedi S. Molecular architecture of early dissemination and massive second wave of the SARS-CoV-2 virus in a major metropolitan area. MBio. 2020;11(6):e02707-20.

19. Iftimie $\mathrm{S}$, López-Azcona $\mathrm{AF}$, Vallverdú I, Hernández-Flix S, De Febrer G, Parra S, et al. First and second waves of coronavirus disease-19: A comparative study in hospitalized patients in Reus, Spain. PloS one. 2021;16(3):e0248029.

20. Josh J. How the second wave of the coronavirus is different from the first wave in terms of symptoms, spread, age profile and mutant variants. National/India current affairs. 2021.

21. Callaway E. The coronavirus is mutating--does it matter?. Nature. 2020;585(7824):174-8.

22. Oran DP, Topol EJ. Prevalence of asymptomatic SARS-CoV-2 infection: a narrative review. Ann Intern Med. 2020;173(5):362-7.

23. Zhou P, Yang XL, Wang XG, Hu B, Zhang L, Zhang W, Si HR, Zhu Y, Li B, Huang CL, Chen HD. A pneumonia outbreak associated with a new coronavirus of probable bat origin. nature. 2020;579 (7798):270-3.

24. Chan JF, Kok KH, Zhu Z, Chu H, To KK, Yuan S, Yuen KY. Genomic characterization of the 2019 novel human-pathogenic coronavirus isolated from a patient with atypical pneumonia after visiting Wuhan. Emerg microbes infect. 2020;9(1):221-36.

25. Shang J, Ye G, Shi K, Wan Y, Luo C, Aihara H, Geng Q, Auerbach A, Li F. Structural basis of receptor recognition by SARS-CoV-2. Nature. 2020;581 (7807): 221-4.

26. Hou Y, Zhao J, Martin W, Kallianpur A, Chung MK, Jehi L, Sharifi N, Erzurum S, Eng C, Cheng F. New insights into genetic susceptibility of COVID-19: an ACE2 and TMPRSS2 polymorphism analysis. BMC Med. 2020;18(1):1-8.

27. Rahimi F, Abadi AT. Implications of the Emergence of a New Variant of SARS-CoV-2, VUI-202012/01. Arch Med Res. 2021.
28. Franceschi VB, Caldana GD, de Menezes Mayer A, Cybis GB, Neves CA, Ferrareze PA, Demoliner M, de Almeida PR, Gularte JS, Hansen AW, Weber MN. Genomic epidemiology of SARS-CoV-2 in Esteio, Rio Grande do Sul, Brazil. BMC genomics. 2021; 22(1):1-7.

29. Srivastava S, Banu S, Singh P, Sowpati DT, Mishra RK. SARS-CoV-2 genomics: An Indian perspective on sequencing viral variants. J. Biosci. 2021;46(1): 14.

30. Lemmermann NA, Lieb B, Laufs T, Renzaho A, Runkel S, Kohnen W, et al. SARS-CoV-2 genome surveillance in Mainz, Germany, reveals convergent origin of the N501Y spike mutation in a hospital setting. medRxiv. 2021.

31. Zhou P, Yang XL, Wang XG, Hu B, Zhang L, Zhang $\mathrm{W}$, et al. A pneumonia outbreak associated with a new coronavirus of probable bat origin. nature. 2020;579(7798):270-3.

32. Letko M, Marzi A, Munster V. Functional assessment of cell entry and receptor usage for SARS-CoV-2 and other lineage B betacoronaviruses. Nat Microbiol. 2020;5(4):562-9.

33. Grubaugh ND, Petrone ME, Holmes EC. We shouldn't worry when a virus mutates during disease outbreaks. Nat microbiol. 2020;5(4):529-30.

34. Vasilarou M, Alachiotis N, Garefalaki J, Beloukas A, Pavlidis P. Population genomics insights into the recent evolution of SARS-CoV-2. BioRxiv. 2020.

35. Dalamaga M, Christodoulatos GS, Karampela I, Vallianou N, Apovian CM. Understanding the coepidemic of obesity and COVID-19: Current evidence, comparison with previous epidemics, mechanisms, and preventive and therapeutic perspectives. Curr Obes Rep. 2021;2:1-30.

36. Bikbov B, Bikbov A. Communication on COVID-19 to community-measures to prevent a second wave of epidemic.

37. Liu X, Liu C, Liu G, Luo W, Xia N. COVID-19: Progress in diagnostics, therapy and vaccination. Theranostics. 2020;10(17):7821.

38. O'Shea J, Prausnitz MR, Rouphael N. Dissolvable microneedle patches to enable increased access to vaccines against SARS-CoV-2 and future pandemic outbreaks. Vaccines. 2021;9(4):320.

39. Samudrala PK, Kumar P, Choudhary K, Thakur N, Wadekar GS, Dayaramani R, Agrawal M, Alexander A. Virology, pathogenesis, diagnosis and in-line treatment of COVID-19. Eur J Pharmacol. 2020;883:173375.

40. Asselah T, Durantel D, Pasmant E, Lau G, Schinazi RF. COVID-19: Discovery, diagnostics and drug development. J Hepatol. 2021;74(1):168-84.

41. Kifle ZD, Ayele AG, Enyew EF. Drug Repurposing Approach, Potential Drugs, and Novel Drug Targets for COVID-19 Treatment. J environ public health. 2021;2021.

42. Callard F. Very, very mild: Covid-19 symptoms and illness classification. Somatosphere. 2020. 
43. Fisayo T, Tsukagoshi S. Three waves of the COVID19 pandemic. Postgrad Mel J. 2020; 97(1147):332.
Cite this article as: Sharaf $S$, Athikkavil FM, Varghese SD, Sreekumar S, Ramakrishnan R, Varghese J, et al. COVID-19: global pandemic with divergent waves: an exigent public health concern worldwide with special context to Indian scenario Int J Community Med Public Health 2022;9:1547-55. 